\title{
Management of a Complex Basilar Invagination Case with Multiple Revision Surgeries - Case Report
}

\section{Tratamento de invaginação basilar complexa com múltiplas cirurgias de correção - relato de caso}

\author{
Carlos Eduardo Vasconcelos Miranda ${ }^{1}$ Hélio Henrique Jorge Torres ${ }^{1}$ Guilherme Cardinali Barreiro ${ }^{2}$ \\ Andrei F. Joaquim ${ }^{1}$ Helder Tedeschi ${ }^{1}$
}

${ }^{1}$ Department of Neurology, Neurosurgery Division, Universidade
Estadual de Campinas Campinas, SP, Brazil
${ }^{2}$ Division of Plastic Surgery, Universidade de São Paulo, Medical
School, São Paulo, SP, Brazil and Universidade Estadual de Campinas,
Campinas, SP, Brazil

Address for correspondence Andrei F. Joaquim, MD, PhD, Rua Antônio Lapa 280, S 506 Cambui, Campinas, SP, Brazil 13025-240 (e-mail: andjoaquim@yahoo.com).

Arq Bras Neurocir 2017;36:62-65.

\begin{abstract}
We describe a Basilar Invagination (BI) case with craniocervical instability and many previous failure surgeries and poor wound coverage. The patient had been submitted to a large posterior fossa craniectomy (which greatly limited the availability of an adequate area for bone fixation) and showed a poor quality of the surgical wound in the posterior craniocervical region. We performed an occipito-cervical fixation, using the bone overlying the torculla as a point of cranial fixation. Craniocervical realignment was achieved by the use of distractive maneuvers with occipital rods, followed by coverage of the hardware via a pedicled longitudinal trapeze myocutaneous flap. We used local ribs removed from the region where

Keywords

- basilar invagination

- craniocervical junction

- wound infection

\section{Resumo}

\section{Palavras-chave}

- invaginação basilar

- junção craniocervical

- infecção de ferida the myocutaneous flap was harvested as autologous bone grafts for craniocervical fusion. Post-operatively, the patient was placed in a halo-vest for three months. The patient improved substantially after the procedure, recovered some muscular strength and experienced total relief of her pain. We hereby discuss the surgical strategy used for treating this complex case in details, with illustrative pictures.

Descrevemos caso de paciente com diagnóstico de invaginação basilar e instabilidade crânio cervical com múltiplas cirurgias prévias e deiscência de ferida operatória. Devido a falha de osso na escama occipital, assim como da cobertura cutânea adequada, realizamos realinhamento craniocervical, com descompressão indireta anterior, fixação occipitocervical na região da tórcula e cobertura da pele com flap miocutâneo longitudinal pediculado de trapézio. As costelas removidas da região do retalho miocutâneo foram transferidas para serem usadas como enxerto autólogo de osso para fusão craniocervical. No pós-operatório, a paciente utilizou um halo-vest por 3 meses. No presente artigo, apresentamos nuances ilustrados de manobras para realinhamento craniocervical por via posterior na invaginação basilar, bem como estratégias para otimizar a artrodese e o fechamento cutâneo.
\end{abstract}

received

May 21, 2015

accepted

November 30, 2015

published online

February 24, 2016
Copyright @ 2017 by Thieme Revinter

Publicações Ltda, Rio de Janeiro, Brazil
License terms

다 (i) $\ominus$ (\$) 


\section{Introduction}

Basilar invagination (BI) is one of the most common craniocervical junction congenital anomalies. ${ }^{1,2}$ The diagnosis is made in the presence of a prolapsed upper cervical spine into the skull-base, precisely when the tip of the odontoid process is located at least $2 \mathrm{~mm}$ above of the Chamberlain line. ${ }^{1,2}$

Many other bone anomalies are associated with BI, such as clival, occipital condyle, or atlas hypoplasia, atlantoccipital assimilation and congenital atlantoaxial instability. ${ }^{3-5}$ Tonsillar herniation, syringomyelia, and hydrocephalus are neural axis anomalies commonly found associated with BI as well. $^{2}$

Patients may present clinical symptoms at all ages, but the majority of them are symptomatic in the second or third decades of life. ${ }^{4}$ Symptoms and signs may include cervical pain, torticollis or limited neck movements, neurological deficits, such as muscular weakness, gait abnormalities, bladder dysfunction or even lower cranial nerves dysfunction, especially swallowing problems.

Surgical treatment is generally indicated in the presence of symptoms. ${ }^{5}$ However, the management of BI patients is quite complex and depends on the site of neural tissue compression, on the presence or absence of craniocervical instability, on the presence of syrinx or tonsillar herniation, and on the surgeon's experience, among others. 3,5,6

In this paper, we present a case of a 42 -year-old woman with multiple previous craniocervical junction surgeries for treatment of BI with craniocervical instability and severe wound problems due to her previous wound infections and hardware exposure. We discuss the strategies used to restore the craniocervical alignment, performing neural decompression and fusion, and those that were used to provide an adequate wound closure.

\section{Case Report}

A 42-year-old woman was referred to our outpatient clinic in 2012 for treatment of refractory cervical pain after failed "Chiari I malformation" surgery. She presented with global muscular weakness (muscular strength grade IV) and pyramidal signs. Her ambulation was severely limited by her pain. On a two-year-span she had undergone five surgical procedures in another hospital that included a posterior fossa decompression with duraplasty, an occipito-cervical instrumented fusion, and three other procedures aimed at the treatment of complications of the former surgeries (one for hardware removal and two for wound debridement) (- Fig. 1-Initial CT scan at our institution admission).

Two weeks after her admission to our institution, we performed a revision surgery for treating her pain due to craniocervical instability. The patient was put on a preoperative cranial traction for realignment of the craniocervical junction for two days and underwent an occipito-cervical instrumented fusion. The skin coverage was quite poor and all layers, including the posterior craniocervical muscles, were very thin. Due to the lack of posterior fossa bone (removed in the previous surgeries), we had to fixate the occipital portion of the rods on the edges of the remaining occipital bone, using wiring techniques, and connected the rods with the subaxial cervical spine using lateral mass screws. After surgery, the patient had almost total relief of her cervical pain and also some muscular improvement (-Fig. 1). However, five months after the procedure, due to her poor wound coverage, the occipital hardware was exposed, and after a short period of intravenous antibiotics had to be removed (-Fig. 2). A local pedicled graft was rotated to cover the skin breakage by the Head and Neck team of our institution. We maintained the subaxial cervical spine instrumentation as we judged that a future reconstruction would probably be necessary. After the removal of the occipital hardware, the cervical pain recurred with important clinical limitations.

Six months after that, in a final surgical attempt to restore the craniocervical alignment, an occipital plate was placed in the region of the torculla, where there was still some occipital bone left. Instead of preoperative traction we used intraoperative distraction maneuvers for decreasing the prolapsed tip of the odontoid into the foramen magnum, resulting in good craniocervical realignment ( - Fig. 3A and 3B). Finally, the plastic surgery team achieved adequate wound coverage with a pedicled longitudinal trapeze myocutaneous flap. The rib from the region of the muscular flap was harvested and used as a bone graft ( - Fig. 3C and 3D).

After surgery, the patient wore a custom-made halo vest for three months and had her wound cared for weekly to avoid skin breakage.

Early pain control was observed in the hospital discharge. Bone fusion was observed in the three months postoperative $\mathrm{CT}$ and the patient had only mild pain after six months of surgery, with occasional use of analgesics. Fusion was totally achieved after four months, as demonstrated in the postoperative CT scan (-Fig. 4 ).

\section{Discussion}

Surgical treatment of BI must be individualized according to the patient's anatomy, since most of the craniocervical malformations are unique. Surgical procedures may range from an isolated posterior fossa decompression to complex craniocervical reconstructions, realignment, and instrumented fusions, or even transoral decompressions in cases of irreducible anterior compression. ${ }^{1,3}$

Patients may have important clinical improvement after adequate surgical treatment. ${ }^{1,2,7}$ Failed surgery may occur for several reasons, such as inability to recognize atlantoaxial instability, wound dehiscence with hardware exposure, incomplete decompression of the neural tissue, and failure in realigning the craniocervical junction with persistent spinal cord or brainstem compression, among others. ${ }^{8,9}$

In the presented case, the causes of surgical failure were many: local infection compromising the skin quality and bone fusion, loss of an adequate site for occipital bone fixation due to an excessive occipital bone removal in the previous surgeries, and, finally, inadequate surgical planning. In the revision surgery, we addressed all the potential issues 


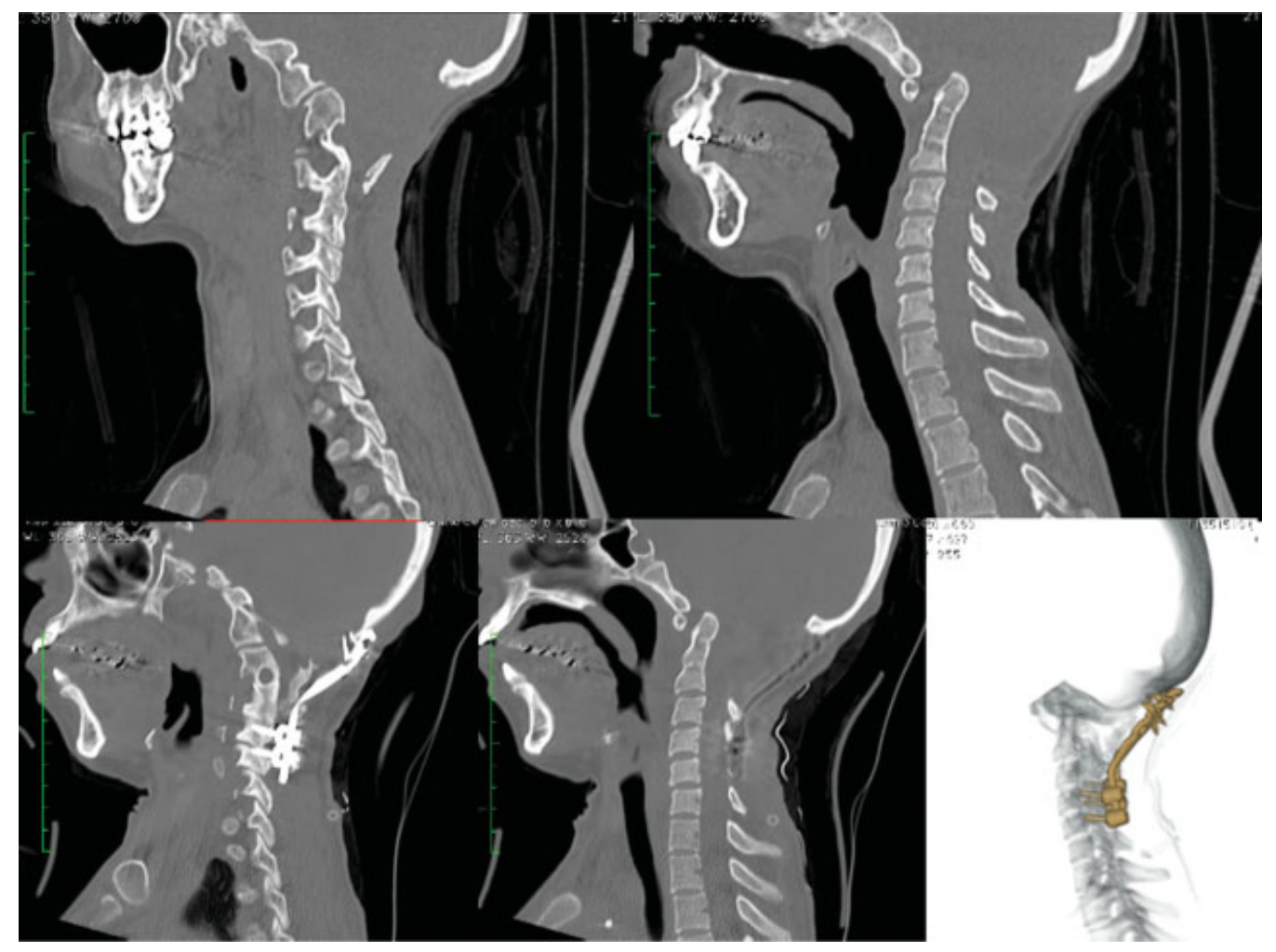

Fig. 1 Preoperative CT scan at the admission in our institution. (A) Sagittal CT scan showing listhesis of the atlantoaxial joint and (B) basilar invagination with the tip of the odontoid protruding into the foramen magnum. Note that the posterior fossa bone was completely removed. (C) CT scan after traction and the first occipito-cervical fusion with wiring techniques in the edges of the remained occipital bone. (D) Sagittal CT scan showing reduction of the protruding dens as well as reduction of the atlantoaxial listhesis. (E) CT scan reconstruction with craniocervical instrumentation.
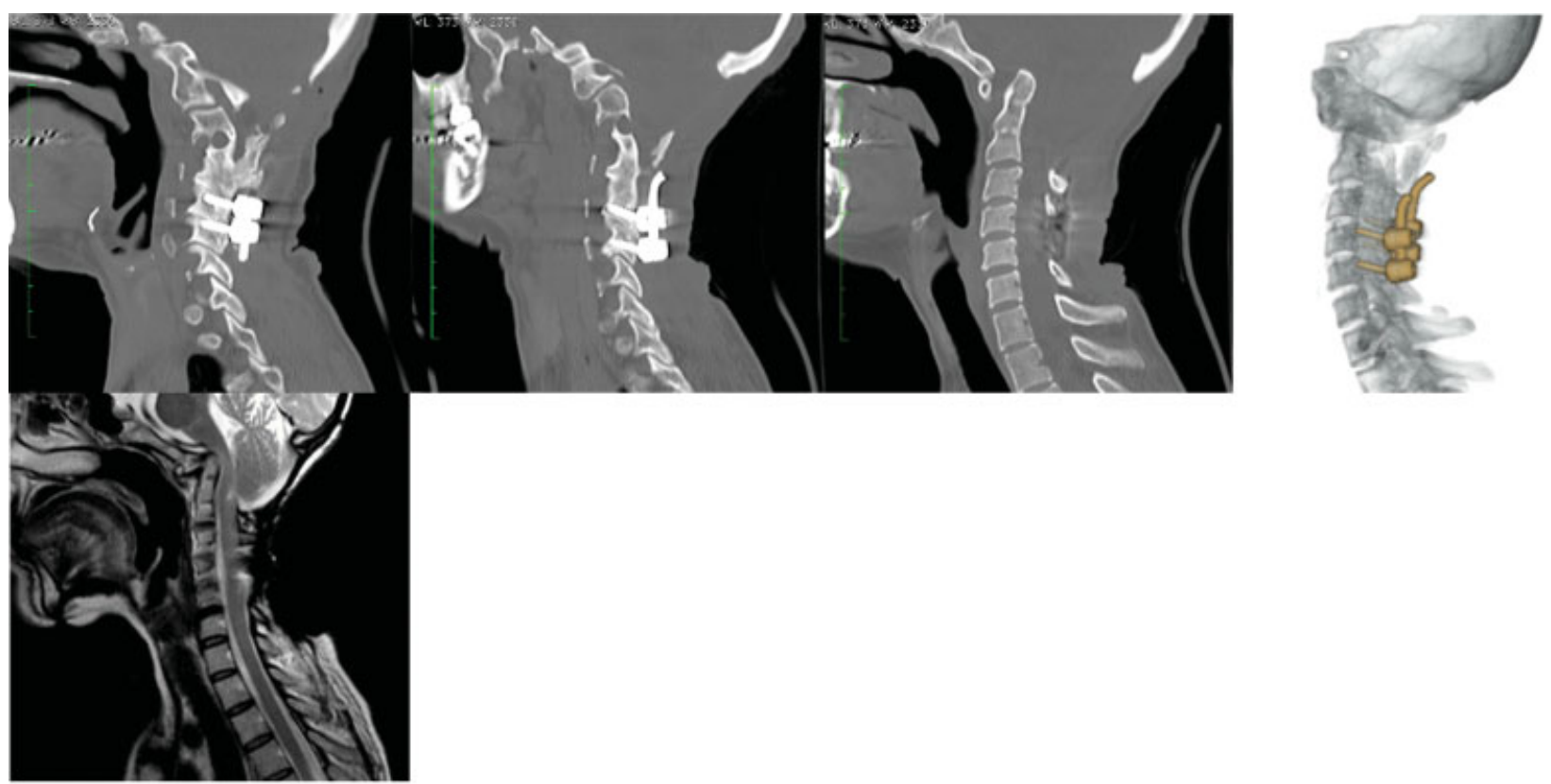

Fig. 2 CT scan after removing the occipital harwdare after wound breakage. (A), (B), and (C): sagittal CT scan showing the subaxial instrumentation and pseudoarthrosis with non-union of the craniocervical junction. (D) CT scan reconstruction with the rods attached in the subaxial spine. (E) Sagittal T2 sequence MRI showing severe anterior brainstem compression at the craniocervical junction and the posterior fossa totally decompressed. 


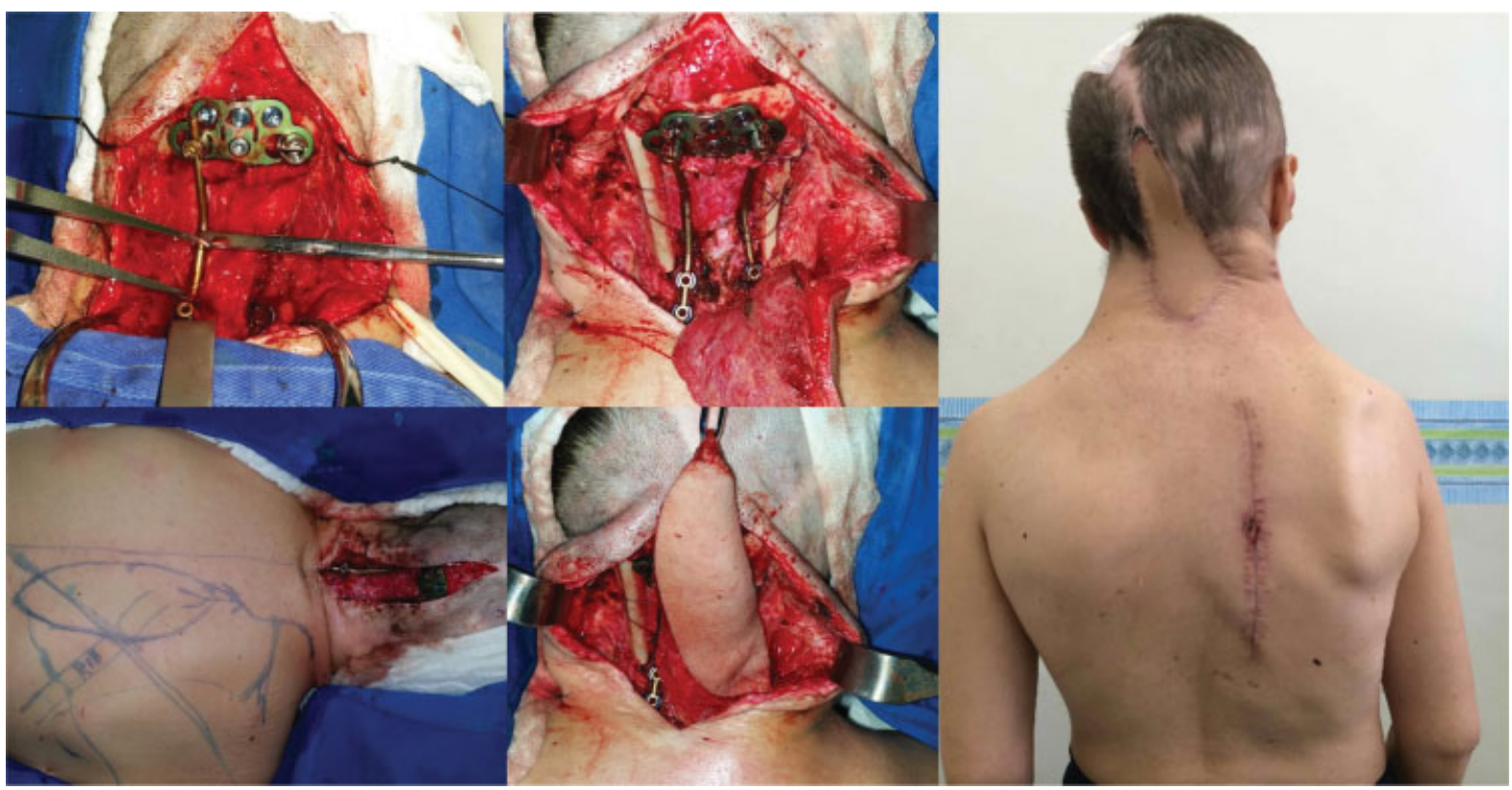

Fig. 3 (A) Intraoperative distraction of the occipital-cervical fixation to reduce the invagination of the dens out of the foramen magnum and (B) final occipito-cervical fusion with bilateral ribs grafts harvested from the region of the flap. (C) The region of the harvest pediculated longitudinal trapeze myocutaneous flap was drawn and (D) the flap positioned in the craniocervical region just before skin closure. (E) Good skin coverage was obtained after wound healing.

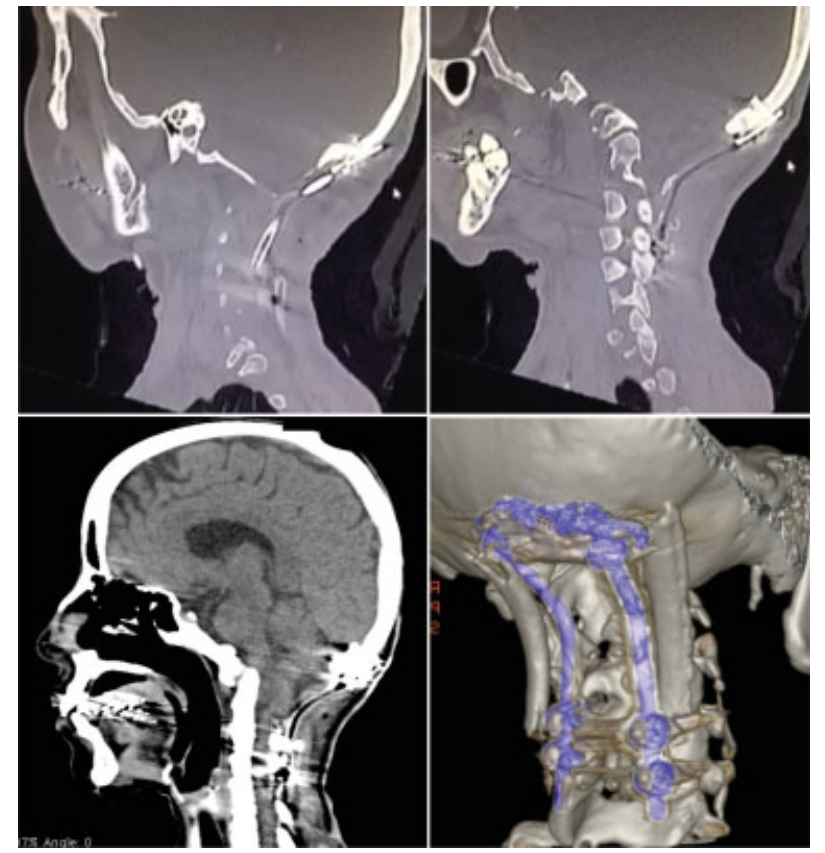

Fig. 4 Postoperative CT sagittal CT scan (A) with the rib graft been visualized from the subaxial cervical spine to the occipital bone and (B) reduction of the atlantoaxial listhesis. (C) Final CT scan with good craniocervical realignment and (D) 4 months CT scan reconstruction with the ribs fusioning the occipital bone and the subaxial spine. The patient had just occasional mild cervical pain and was ambulating without help.

related to failure, including postoperative planning, such as the use of a halo-vest for potentially improving the fusion rate in a patient with poor bone quality and previous failure. ${ }^{1}$

\section{Conclusion}

As final conclusion, craniocervical junction anomalies may require a multidisciplinary team for addressing all the complex issues involved in their treatment, to achieve better outcomes and surgical results. It is, thus, mandatory that all the potential aspects that may cause surgical failure be considered in the management of BI.

\section{References}

1 Joaquim AF, Ghizoni E, Giacomini LA, Tedeschi H, Patel AA. Basilar invagination: Surgical results. J Craniovertebr Junction Spine 2014;5(2):78-84

2 Joaquim AF. Management of Basilar Invagination. J Bras Neurocirurg 2013;24(1):53-59

3 Joaquim AF, Fernandes YB, Mathias RN, et al. Incidence of basilar invagination in patients with tonsillar herniation? A case control craniometrical study. Arq Neuropsiquiatr 2014;72(9):706-711

4 Goel A, Shah A. Atlantoaxial joint distraction as a treatment for basilar invagination: a report of an experience with 11 cases. Neurol India 2008;56(2):144-150

5 Goel A. Instability and basilar invagination. J Craniovertebr Junction Spine 2012;3(1):1-2

6 Goel A. Basilar invagination, Chiari malformation, syringomyelia: a review. Neurol India 2009;57(3):235-246 [serial online]

7 Schmideck HH, Sweet WH. Operative neurosurgical techniques: indications, methods and results. $6^{\text {th }}$ ed. / [edited by] Alfredo Quiñones-Hinojosa. p. 2055-70. 2012

8 Schimmel JJP, Horsting PP, de Kleuver M, Wonders G, van Limbeek J. Risk factors for deep surgical site infections after spinal fusion. Eur Spine J 2010;19(10):1711-1719

9 Kasliwal MK, Tan LA, Traynelis VC. Infection with spinal instrumentation: Review of pathogenesis, diagnosis, prevention, and management. Surg Neurol Int 2013;4(Suppl 5):S392-S403 